\title{
An Ultrasonic Accelerated Three-Component Condensation By KCC-1: A High Mechanical Stability Silica Nanospheres As A Good Catalyst For Ultrasonic Irradiation
}

Hourieh Sadat Oboudatian

University of Kashan

Javad Safaei-Ghomi ( $\nabla$ safaei@kashanu.ac.ir)

University of Kashan

\section{Research Article}

Keywords: Fibrous, nanocatalyst, ultrasonic irradiation, spectroscopy

Posted Date: November 10th, 2021

DOI: https://doi.org/10.21203/rs.3.rs-966027/v1

License: (c) (1) This work is licensed under a Creative Commons Attribution 4.0 International License.

Read Full License 


\section{Abstract}

Fibrous nano-silica sphere (KCC-1) has appeared as a good and efficient catalyst for ultrasonic irradiation conditions in chemical reactions. This catalyst has the unique properties such as a fibrous surface morphology, high surface area and high mechanical stability. The results indicated that the KCC-1 nanocatalyst could be used as high-performance catalysts under high temperature and pressure condition in organic reaction under ultrasonic irradiation. Morphology, structure, and composition of the fibrous nano-silica sphere were described by N2 adsorption-desorption analysis, scanning electron microscopy (SEM), transmission electron microscopy (TEM), X-ray powder diffraction (XRD), thermogravimetric analysis (TGA) and Fourier-transform infrared spectroscopy (FT-IR). In this work, we used KCC-1@ $\mathrm{NH}_{2}$ nanosilica as a basic catalyst for the preparation of chromenes under ultrasonic irradiation conditions for the first time. The recyclability, nontoxicity and high stability of the catalyst, combined with low reaction times and excellent yields, make the present protocol very useful for the synthesis of the title products under ultrasonic conditions. The produced products were confirmed via ${ }^{1} \mathrm{H}$ NMR, ${ }^{13} \mathrm{C}$ NMR, FT-IR analysis.

\section{Introduction}

In recent years, many studies have been concentrated on increasing the performance of organic catalytic synthesis because of their applicable importance. One of the progressive strategies which have recently attracted considerable attention is the usage of ultrasound conditions with heterogeneous catalysts. 2Amino-4H-chromenes are an important class for further development in medicinal and organic synthesis studies due to their potency and a wide spectrum of biological activities including cancer therapy ${ }^{1,2}$, antiviral $^{3,4}$, antitumor ${ }^{5}$ and sex hormone ${ }^{6}$. For example (Figure 1), pyranopyranone (1) as an ancestor for the blood anticoagulant warfarin, ${ }^{7}$ (4H-chromen-4-yl)cyanoacetate (2) as inhibitor of Bcl-2 protein and apoptosis inducer ${ }^{8}$ and benzopyrane (3) has been known for anticancer therapeutic. ${ }^{9}$ Also compounds 4 and 5 showed in Figure 1 the maximum inhibitory effect against the HT29 human colon cancer cells. ${ }^{10}$ Chromenes have been used for the treatment of different diseases of connective tissues, diabetes, psoriasis, pernicious anemia, ulcerous colitis, and chronic hepatitis. ${ }^{11}$ These derivatives are employed as a building block of many natural products ${ }^{12,13}$, food additives, Pigments, Pesticides, cosmetic agents and potentially biodegradable agrochemicals ${ }^{14}$.

The preparation of 2-Amino-4H-Chromenes has been reported using various conditions and catalysts such as piperidine ${ }^{15,16}$, piperazine ${ }^{17}$, triethyl amine ${ }^{18}, \mathrm{IL}^{19}, \mathrm{MCM}-41^{20}, \mathrm{~K}_{2} \mathrm{CO}_{3}{ }^{21}$. Most of the reported methods need long reaction times, use of toxic solvents, low yields, non-reusable catalysts and stoichiometric reagents. In the present paper, we utilized acoustic cavitation. That is a physical phenomenon that helps chemical reactions under ultrasound irradiation. Ultrasound has been known as significant for green and remarkable synthetic methods. ${ }^{22-24}$ The ultrasound approach reduces times, increases yields of products by creating the activation energy in micro surroundings. ${ }^{25,26}$ This 
phenomenon is generally contained the construction, growth, and transient implosive collapse of the gas and vapour filled microbubbles. The physical and chemical effects of cavitation are exciting for various applications. ${ }^{27}$

This method indicates bubble-sphere interaction on a microscale. The presence of suspended spherical particles near to substances of reactant could potentially have an important effect on bubble dynamics. ${ }^{28,29}$ Precipitate implosion of these bubbles in the liquids creates localized hot spots with very short lifetimes. The hot spot has an equivalent temperature of $5000^{\circ} \mathrm{C}$ and pressure of about 2000 atmospheres can achieve upon the destruction of the bubble. ${ }^{30}$ In this condition, the physical properties of the catalyst, including good thermal, hydrothermal, and high mechanical stabilities are very important.

Catalyst scientists and nanotechnology have helped a lot in this regard. Importantly, in our search of nanocatalysts, we used dendritic silica nanospheres (KCC-1) as the catalyst. ${ }^{31-33}$ Fibrous nano-silica sphere (KCC-1) compared to MCM-41 and SBA-15-supported catalysts, shows excellent physical properties, including a high surface area, a fibrous surface morphology, good thermal/hydrothermal properties and high mechanical stability. The fibrous morphology observed in these nanospheres making it easily accessible. Dendritic silica nanospheres endure unaffected even after mechanical compression up to $216 \mathrm{MPa}$ pressure whereas the conventional MCM-41 type of silica, which is endured at pressure 86 Mpa. $^{32}$

In the synthesis of fibrous nano-silica (KCC-1), we can control particle size, fiber density, surface area and pore volume of KCC-1 and tune by changing various reaction parameters, such as the concentrations of urea, CTAB, 1-pentanol, reaction time, temperature, solvent ratio, and even outside stirring time. ${ }^{34} \mathrm{KCC}-1$ can be used as catalyst support, sorbent or carrier. Due to the unique properties of silica is used in various organic reactions, ${ }^{35-38}$ drug delivery systems and biomedical applications, ${ }^{39}$ optoelectronic devices, ${ }^{40}$ modern industries, ${ }^{41-44}$ gas capture, solar energy harvesting ${ }^{45,46}$ and many others. All in all, it is the fibrous morphology of KCC-1 that produces better accessibility of the active sites for enhanced catalytic activities and recovery efficiencies. As well as the mechanical and thermal stability of KCC-1 that provides the better heterogeneous catalyst for ultrasonic irradiation conditions. We chosed, the ultrasonic route for the synthesis of 2-amino chromenes with modified dendritic silica nanosphere with amine groups present on the surface ( $\left.\mathrm{KCC}-1 @ \mathrm{NH}_{2}\right)$ and distinct factors such as time of ultrasonic reaction and power of ultrasound utilized for optimizing the condition of reaction.

\section{Results And Discussion}

\section{Structural analysis of the KCC-1@NH 2 nanocatalyst}

In this study, first fibrous nanosilica spheres was prepared with the methods was reported by Bayal and coworkers. ${ }^{34}$ In the second stage, a $\mathrm{NH}_{2}$ shell using APTES (aminopropyltriethoxysilane) was coated on 
the nanosilica core. The $\mathrm{KCC}-1 @ \mathrm{NH}_{2}$ nanocatalyst was as an efficient basic catalyst for the preparation of 2-Amino-4H-chromenes (scheme 1).

The IR patterns of different stages of nanosilica preparation are showed in Fig. 2. The characteristic peaks of the silica-based materials could be observed in the range of 1092 to $1150 \mathrm{~cm}^{-1}$ representing the Si-O-Si asymmetric stretching while a Si-OH peak is observed at $812 \mathrm{~cm}^{-1}$, which represents the stretching vibration and symmetric bending (Fig. 2b). In addition, the peaks at around $2930 \mathrm{~cm}^{-1}$ can be assigned to the $-\mathrm{CH}$ stretching frequency derived from the $\mathrm{CH}_{2}$ groups of the alkyl chains (Fig. 2c). These FT-IR spectral features indicated the successful functionalization of APTES over KCC-1.

The XRD pattern of nanosilica spheres $\left(\mathrm{KCC}-1 @ \mathrm{NH}_{2}\right)$ is depicted in Fig. 3. This figure reveals high phase purity of the nanocatalyst and has a perfect agreement with the reported XRD pattern for nanosilica spheres $\left(\mathrm{KCC}-1 @ \mathrm{NH}_{2}\right)$ (JCPDS No. 71-1232). The XRD pattern of $\mathrm{KCC}-1 @ \mathrm{NH}_{2}$ includes peaks from $\mathrm{SiO}_{2}$ and Organic layer on this catalyst. The average crystalline size of the nanocatalyst was calculated to be 8 $\mathrm{nm}$ that was obtained from FWHM Scherrer's formula.

The elemental compositions of the fibrous nanosilica spheres $\left(\mathrm{KCC}-1 @ \mathrm{NH}_{2}\right)$ were demonstrated by EDX. Energy Dispersive Spectroscopy (Fig. 4) confirmed the presence of $\mathrm{Si}, \mathrm{O}, \mathrm{C}$ and $\mathrm{N}$ in the nanocatalyst. By the scanning electron microscopy (SEM) image, morphology, and particle size of fibrous nanosilica spheres (KCC-1@NH $\left.{ }_{2}\right)$ is confirmed (Fig. 5). Figure 5a indicates a FE SEM image of nanosphere KCC$1 @ \mathrm{NH}_{2}$ samples, where the samples have spheres of uniform size with average diameters of $95 \mathrm{~nm}$ and the nanoparticles show good dispersity with spherical morphology. The SEM image of the reused catalyst for six runs is shown in figure $5 \mathrm{~b}$. This image is confirmed the high stability of the reused nanocatalyst after five runs.

The TEM image of the KCC-1@ $\mathrm{NH}_{2}$ nanocatalyst (Figure $5 \mathrm{~d}$ ) demonstrates that wrinkled fibers grow out from the center of the spheres and are arranged radially in three dimensions. The TEM image provides more exact information about the particle size and morphology of the nanomaterial. The TEM image tells the spherical shape of the nanosilica, with an average size of $97 \mathrm{~nm}$, which shows near agreement with the value determined via SEM. The FE SEM and TEM image indicates that the entire sphere is solid and composed of spherical.

Nitrogen adsorption-desorption isotherms analysis and BJH pore size distributions are done to evaluate the surface and structure properties of KCC-1@ $\mathrm{NH}_{2}$ (Figure 6). According to the International Union of Pure and Applied Chemistry (IUPAC) classification, this catalyst indicated characteristic type IV curve, which is consistent with literature reports on standard fibrous silica spheres. $\mathrm{H} 2$ type hysteresis loop in the relative pressure ranges from 0.4 to 1.00 , is attributed to mesopore materials. For KCC-1@ $\mathrm{NH}_{2}$, the BET surface areas were $297 \mathrm{~m}^{2} \mathrm{~g}^{-1}$; pore diameters were $8.32 \mathrm{~nm}$; and pore volumes $0.62 \mathrm{~cm}^{3} \mathrm{~g}^{-1}$, respectively. 
The thermal behavior of nanosilica spheres $\left(\mathrm{KCC}-1 @ \mathrm{NH}_{2}\right)$ is shown in Figure 7. The TG profile exhibits two steps of weight loss. The initial mass loss of $5 \%$ accrued with an endothermic peak in DTA curve is revealed in the temperature range of $80-144^{\circ} \mathrm{C}$. It can be related to the release of physically absorbed water or solvent on the surface of the $\mathrm{KCC}-1 @ \mathrm{NH}_{2}$ and other raw materials. The second mass loss of $20 \%$ in a wide temperature range of $440-640^{\circ} \mathrm{C}$ was overlapping a broad endothermic DTA peak. It corresponds mainly to the thermal decomposition of the organic group. The results of the thermal analysis expressed that the thermal decomposition of organic moiety completed at a temperature of $823^{\circ} \mathrm{C}$.

\section{Synthesis of 2-amino-4H-chromenes catalyzed by nanosilica KCC-1@NH 2}

Chromenes derivatives have been prepared from the Knoevenagel condensation of 1,5-naphtalenediol, malononitrile and aromatic aldehydes compounds catalyzed by nanosilica at $20 \mathrm{kHz}$ frequency and $80 \mathrm{~W}$ power for an appropriate time under ultrasound irradiation as drawn in Scheme 2.

The effect of experimental factors comprising type and amount of catalyst, different powers of ultrasound irradiation, different solvents and effects of different donor or withdrawing substitutions of aldehydes were investigated to find the best condition for this reaction and the results are listed in Tables For this purpose, the reaction between 4-chlorobenzaldehyde $(1.0 \mathrm{mmol})$, malononitriles $(1.0 \mathrm{mmol})$, and 1,5-dinaphtol $(0.5 \mathrm{mmol})$ as substrates by prepared nanosphere as a catalyst under ultrasonic conditions was selected as the model reaction. At first, the optimum amount of catalyst was investigated in ethanol solvent (Table 1).

With reference to the results shown in Table 1, the optimized quantity of nanocatalyst for this synthesis is $0.05 \mathrm{~g}$ (Table 1, entry 5). In an effort to obtain better yields and the most effective solvent, various solvents were used for the synthesis of chromenes. The examination of solvent was demonstrated that ethanol as protic solvent is the best condition for the Knoevenagel condensation of benzaldehydes and malononitrile compounds (Table 1, entry 5). Comparison of this entry with entries 8-9 of Table 1 (various catalysts containing piperidine and $\mathrm{NEt}_{3}$ ) reveals that the nanocatalyst is the most efficient catalyst for the sonochemical synthesis of 2-amino chromenes.

Evaluation of thermal and ultrasound conditions shows that the ultrasonic approach is very effective for this synthesis is presented in Table 1. When the 2-Aminochromenes derivatives were synthesized under the heating method (entry 10, Table 1), they were produced in lower yields at higher reaction times, but performing these reactions under sonication conditions created excellent yields of 2-Aminochromenes at short times. Therefore, because of its basic green chemistry conception, the shock wave and microjet generated by the cavitation, this method is more environmentally benign. During the ultrasonic irradiation, KCC-1@ $@ \mathrm{NH}_{2}$ nanocatalyst like a wall for the transmission of the bubble, is dispersed in the reaction and 
affords more sites for the generation of the number of micro-bubbles. Increasing of micro-cavities may advance the helpfulness of the ultrasound approach to the formation of 2-Aminochromenes. ${ }^{35-38}$

In continues, to detect the suitable power of ultrasonic irradiation for this reaction, it was tested under different powers of ultrasound irradiation as shown in Table 2. In the end, this reaction is effectively proceeded by $0.05 \mathrm{~g}$ of $\mathrm{KCC}-1 @ \mathrm{NH}_{2}$ nanocatalyst with the power of $80 \mathrm{~W}$ of ultrasonic irradiation. Really in ultrasound irradiation the number of active cavitation bubbles and size of the individual bubbles is to increase. As a result, collapse temperature was increased and accelerated the synthesis of 2-aminochromenes derivatives reaction. Various substituted 2-Aminochromenes were prepared by nanocatalyst using the obtained optimized condition (Table 3). The results were indicated that aromatic aldehydes with electron-withdrawing groups reacted much more faster compared to those with electro-donating groups.

A rational mechanism for the preparation of 2-Aminochromens under ultrasonic irradiation by the KCC$1 @ \mathrm{NH}_{2}$ nanocatalyst is illustrated in Scheme 3. At first, a complex was formed between the carbonyl group of aldehyde and the $\mathrm{NH}_{2}$ group of nanocatalysts. Also, acidic hydrogen of malononitrile was removed. Afterward, by a Knoevenagel condensation, active methylene of malononitrile attacked to aldehyde and affords to intermediate I after removing one molecule of $\mathrm{H}_{2} \mathrm{O}$. Then, 1,5-dinaphthol from $\beta$ position attacks to the cyanoolefin compound (I) to give II. Finally, further aromatization and intramolecular cyclization of II gives III which is converted to the corresponded product. These steps are efficiently offered on the cavitation effect of ultrasound irradiation and also by the high nanosphere surface. Based on this mechanism, it is highly probable that the carbonyl groups of aldehydes and malononitrile compounds have been activated, by the coordination of carbonyl oxygen and KCC- $1 @ \mathrm{NH}_{2}$ nanospheres. Thus KCC-1@ $\mathrm{NH}_{2}$ nanospheres activated of methylene of malononitrile and carbonyl groups. Due to its high surface area increase the rate and yield of the reaction. In addition, the catalyst used is easily filtrated and reused without any noticeable loss of activity after at least five times (Scheme $3)$.

\section{Reusability of KCC-1@NH 2 nanocatalyst}

Reusability and recoverability of Nanosilica spheres $\left(\mathrm{KCC}-1 @ \mathrm{NH}_{2}\right)$ are known as one of the most important properties of the catalyst under ultrasonic conditions. After the completion of reaction, $5 \mathrm{~mL}$ of acetone was added to the reaction mixture. The product solved in acetone and nanosilica was recycled via filtration. The reusability of our catalyst was tested for the model reaction, and it was found that product yields lessened only Nanosilica spheres $\left(\mathrm{KCC}-1 @ \mathrm{NH}_{2}\right)$ are recoverable without a considerable loss of catalytic activity (Fig. 8). It was very important to us that the catalyst was stable in ultrasonic irradiation conditions. Accordingly, we investigated the morphology and particle size of the nanocatalyst before use and after reuse six times in reaction by SEM image as presented in Figures $5 b$ and $5 c$. According to the figures, the morphology of the nanoparticles stayed unchanged. We believe this is also 
the possible reason for the extreme stability of the fibrous nanosilica spheres for ultrasonic irradiation conditions.

In Table 4 was showed different reports in the literature for the synthesis of 2-amino chromenes. Table 4 represents the differences between their results (entries 1-4) and the results of the present research (entry 5). As can be seen the proposed method in this work is the best condition for the synthesis of 2-amino chromenes derivatives. The properties such as mild reaction condition, high yields of 2-amino chromenes, easy recovery of the nanosilica by filtration, reusability of the catalyst for 6 times without significant loss of catalytic performance, short reaction times and environmentally benign of this method makes better than other previous methods. The main drawback of other procedures is a non-reusable catalyst, long reaction time, difficulty in separation of catalyst from the reaction mixture and low efficiency.

\section{Experimental Section}

\section{Substances and method}

Cetyltrimethylammonium bromide (CTAB) $\left(\left[\left(\mathrm{C}_{16} \mathrm{H}_{33}\right) \mathrm{N}\left(\mathrm{CH}_{3}\right)_{3}\right] \mathrm{Br}\right)$, Urea, Tetraethyl orthosilicate $\left(\mathrm{Si}\left(\mathrm{OC}_{2} \mathrm{H}_{5}\right)_{4}\right.$, Merck, $\left.>98 \%\right)$, Cyclohexane, hexanol, (3-Aminopropyl) triethoxysilane (APTES), dried Toluene $\left(\mathrm{C}_{7} \mathrm{H}_{8}\right.$, Merck, $\left.>99.8 \%\right)$, absolute Ethanol $\left(\mathrm{C}_{2} \mathrm{H}_{5} \mathrm{OH}\right.$, Merck, >99.9\%), Malononitril, 1,5-

dihydroxynaphthalene, derivatives Aldehyde were acquired from Merck and Sigma-Aldrich Company. They were used immediately without further filtration and distilled water was used throughout the test.

In this reaction, we were applied the ultrasonic irradiation using a multiwave ultrasonic generator (Sonicator 3200; Bandelin, MS 73, Germany), armed by a converter/transducer and titanium oscillator (horn), $12.5 \mathrm{~mm}$ diameter, operating at $20 \mathrm{kHz}$ with a maximum power output of $200 \mathrm{~W}$. The ultrasonic generator automatically harmonized the power level. Melting points of synthesized products were determined by Electrothermal 9200. IR spectra of synthesized products and different stages of catalyst fabrication were noted by means of FT-IR Magna spectrometer 550 Nicolet using $\mathrm{KBr}$ plates. ${ }^{13} \mathrm{C}$ NMR and ${ }^{1} \mathrm{H}$ NMR spectra were reached in DMSO- $\mathrm{d}_{6}$ as a solvent on Bruker Avance- $400 \mathrm{MHz}$ spectrometers in TMS as an internal standard. The microscopic morphology of the nanoparticles was visualized by the morphological features of the sample were investigated with a Zeiss (EM10C -Germany) transmission electron microscope (TEM) operating at $100 \mathrm{kV}$ and field emission scanning electron microscopy (FE SEM) (MIRA 3 TESCAN). Energy-dispersive X-ray spectroscopy (EDX) of the nanoparticles was imagined by a Sigma ZEISS, Oxford Instruments Field Emission. For surface area measurement was used of Brunauer Emmett Teller (BET) method. It was determined by nitrogen adsorption amount using a mechanized gas adsorption analyzer (Tristar 3000, Micromeritics). Powder XRD of KCC nanoparticles was achieved by a Philips diffractometer of X'pert Company. Thermogravimetric and differential thermal analysis (TGA-DTA) were obtained from a Bahr STA-503 instrument in the air at a heating rate of $10^{\circ} \mathrm{C}$ $\mathrm{min}^{-1}$. The purity determination of the substrates and reaction monitoring was accomplished by TLC on silica gel polygram SILG/UV 254 plates (from Merck Company). 


\section{Preparation of Fibrous Nanosilica Spheres (KCC-1)}

Bayal and coworkers reported the methods of synthesizing of KCC- ${ }^{34}$. Briefly, $1 \mathrm{~g} \mathrm{CTAB}$ was added to 10 $\mathrm{mL}$ deionized water and after $0.6 \mathrm{~g}$ urea was added to the flask, the mixture was stirred for about $3 \mathrm{~h}$ at room temperature. Then, the mixture of $2 \mathrm{~g}$ TEOS, $1.5 \mathrm{~mL}$ hexanol and $30 \mathrm{~mL}$ cyclohexane was added to the flask and sonicated for $30 \mathrm{~min}$. Later, the mixture was refluxed at $120{ }^{\circ} \mathrm{C}$ for $4 \mathrm{~h}$ and afterward refluxed at $80{ }^{\circ} \mathrm{C}$ for $24 \mathrm{~h}$. Then, the mixture was cooled to room temperature and centrifuged to collect the KCC-1 as white Sediment. The collected KCC-1 was washed several times with water and ethanol and dried at $60{ }^{\circ} \mathrm{C}$ for $24 \mathrm{~h}$. Finally, KCC- 1 was calcinated at $550{ }^{\circ} \mathrm{C}$ for $6 \mathrm{~h}$ to remove the CTAB as a templating agent. For this mechanism, urea was added to hydrolyze the TEOS to produce negatively charged $\left(\mathrm{SiO}_{4}\right)_{4}{ }^{-}$silicate. Using of CTAB persuades the silicate molecules to form self-assembled linear structures where the CTAB helps to the aggregating of the silicates. ${ }^{32,47}$

\section{Preparation of KCC-1@ @ $\mathrm{NH}_{2}$}

To functionalize the KCC- 1 surface with $\mathrm{NH}_{2}$ moieties, $0.02 \mathrm{~g}$ of KCC- 1 was dispersed on $1.2 \mathrm{~mL}$ dried toluene and sonicated for $30 \mathrm{~min}$. Then $50 \mu \mathrm{L}$ 3-aminopropyltriethoxysilane (APTES) was added to the mixture and refluxed for $20 \mathrm{~h}$ at $80^{\circ} \mathrm{C}$. Then the mixture was separated and washed with toluene several times and dried at $80{ }^{\circ} \mathrm{C}$ for at least $24 \mathrm{~h}^{48}$.

\section{General procedure for the preparation of 2-Amino-4H- chromenes using functionalized Fibrous Nanosilica Sphere (KCC-1@NH 2 ) under ultrasonic irradiation}

A mixture of 1,5-naphtalenediol (1 mmol), malononitrile $(2 \mathrm{mmol})$ and aromatic aldehydes $(2 \mathrm{mmol})$ and Fibrous Nanosilica Sphere $\left(\mathrm{KCC}-1 @ \mathrm{NH}_{2}\right)(0.05 \mathrm{~g})$ as a catalyst in ethanol $(5 \mathrm{~mL})$ was sonicated at $20 \mathrm{KHz}$ frequency and $80 \mathrm{~W}$ power for required times. The reaction was monitored by TLC. After completion of the reaction, the reaction mixture dissolved with acetone. Then, nanocatalyst was filtered and washed with toluene, dried and re-used for a successive run under the same reaction conditions. Evaporation of the solvent of the residual solution under reduced pressure gave a crude product. The solid product was recrystallized with EtOH to get pure product. The products were characterized based on ${ }^{1} \mathrm{H}-\mathrm{NMR}, \mathrm{FT}-\mathrm{IR}$, and melting point analysis, and the spectral data of the synthesized compounds were compared with authentic samples. The Spectra data of new compounds are presented:

\section{Spectral data.}

3,9-diamino-1,7-bis(3-chlorophenyl)-1,7-dihydrochromeno[8,7-h]chromene-2,8-dicarbonitrile (4d): 92\%, Yellow solid, m.p = 310-315 ${ }^{\circ} \mathrm{C}$ (decomp.), IR $(\mathrm{KBr}) \vee\left(\mathrm{cm}^{-1}\right)$ : $3439\left(\mathrm{NH}_{2}\right), 3327\left(\mathrm{NH}_{2}\right), 3198,2195(\mathrm{CN}), 1649$ $\left(\mathrm{NH}_{2}\right.$ bending), 1595, 1474, 1385, 1280, 1187, 1080 (C-0), 893, 753; ${ }^{1} \mathrm{H}$ NMR (DMSO-d6, $\left.400 \mathrm{MHz}\right) \delta$ 
(ppm): 4.97 (s, 2H, $\left.\mathrm{CH}_{\text {benzyl }}\right), 7.17-7.35\left(\mathrm{~m}, 10 \mathrm{H}, \mathrm{H}_{\text {aromatic }}\right), 7.24$ (br.s, $\left.4 \mathrm{H}, \mathrm{NH}_{2}\right), 7.88-7.90$ (dd, J = $8.4 \mathrm{~Hz}$, $2 \mathrm{H}, \mathrm{H}_{\text {aromatic }}$ ).

3,9-diamino-1,7-bis(3-hydroxyphenyl)-1,7-dihydrochromeno[8,7-h]chromene-2,8-dicarbonitrile (4f): 90\%, Yellow solid, m.p. $>300^{\circ} \mathrm{C}$ (decomp.), IR $(\mathrm{KBr}) \vee\left(\mathrm{cm}^{-1}\right)$ : $3444\left(\mathrm{NH}_{2}\right), 3301\left(\mathrm{NH}_{2}, \mathrm{OH}\right), 2192(\mathrm{CN}), 1652\left(\mathrm{NH}_{2}\right.$ bending), 1596, 1455, 1386, 1280, 1246, 1187, 1081 (C-0), 886, 761; ${ }^{1} \mathrm{H}$ NMR (DMSO-d6, 400 MHz) $\delta$ (ppm): $4.78\left(\mathrm{~s}, 2 \mathrm{H}, \mathrm{CH}_{\text {benzyl }}\right), 6.67-6.69\left(\mathrm{~m}, 4 \mathrm{H}, \mathrm{H}_{\text {aromatic }}\right), 7.07-7.10\left(\mathrm{~m}, 4 \mathrm{H}, \mathrm{H}_{\text {aromatic }}\right), 7.13$ (br.s, $\left.4 \mathrm{H}, \mathrm{NH}_{2}\right)$, 7.22-7.24 (m, 2H, $\left.\mathrm{H}_{\text {aromatic }}\right), 7.86-7.88\left(\mathrm{dd}, \mathrm{J}=8.4 \mathrm{~Hz}, 2 \mathrm{H}, \mathrm{H}_{\text {aromatic }}\right), 9.35(\mathrm{~s}, 2 \mathrm{H}, \mathrm{OH})$.

3,9-diamino-1,7-bis(4-hydroxyphenyl)-1,7-dihydrochromeno[8,7-h]chromene-2,8-dicarbonitrile (4g): 87\%, Yellow solid, m.p. $>300^{\circ} \mathrm{C}$ (decomp.), IR (KBr) v $\left(\mathrm{cm}^{-1}\right)$ : $3422\left(\mathrm{NH}_{2}\right), 3323\left(\mathrm{NH}_{2}, \mathrm{OH}\right), 2923,2180(\mathrm{CN}), 1655$ ( $\mathrm{NH}_{2}$ bending), 1595, 1511, 1389, 1255, 1184, 1085 (C-0), 759; ${ }^{1} \mathrm{H}$ NMR (DMSO-d6, $\left.400 \mathrm{MHz}\right) \delta(\mathrm{ppm})$ : 4.75 (s, 2H, $\left.\mathrm{CH}_{\text {benzyl }}\right), 6.67-6.69$ (d, J = $8 \mathrm{~Hz}, 4 \mathrm{H}, \mathrm{H}_{\text {aromatic }}$ ), 7.00-7.02 (d, J = $8 \mathrm{~Hz}, 4 \mathrm{H}, \mathrm{H}_{\text {aromatic }}$ ), 7.06 (br.s, $\left.4 \mathrm{H}, \mathrm{NH}_{2}\right), 7.17-7.20\left(\mathrm{~d}, \mathrm{~J}=8.8 \mathrm{~Hz}, 2 \mathrm{H}, \mathrm{H}_{\text {aromatic }}\right), 7.83-7.85\left(\mathrm{~d}, \mathrm{~J}=8.4 \mathrm{~Hz}, 2 \mathrm{H}, \mathrm{H}_{\text {aromatic }}\right), 9.34(\mathrm{~s}, 2 \mathrm{H}, \mathrm{OH})$.

3,9-diamino-1,7-bis(2-hydroxyphenyl)-1,7-dihydrochromeno[8,7-h]chromene-2,8-dicarbonitrile (4h): 85\%, Yellow solid, m.p. $>300^{\circ} \mathrm{C}$ (decomp.), IR (KBr) v $\left(\mathrm{cm}^{-1}\right)$ : $3467\left(\mathrm{NH}_{2}\right), 3332\left(\mathrm{NH}_{2}, \mathrm{OH}\right), 3196,2192(\mathrm{CN}), 1650$ ( $\mathrm{NH}_{2}$ bending), 1595, 1461, 1383, 1280, 1187, 1080 (C-0), 889, 799; ${ }^{1} \mathrm{H}$ NMR (DMSO-d6, $\left.400 \mathrm{MHz}\right) \delta$ (ppm): 5.11 (s, 2H, $\left.\mathrm{CH}_{\text {benzyl }}\right), 6.91-6.93\left(\mathrm{~d}, \mathrm{~J}=7.2 \mathrm{~Hz}, 2 \mathrm{H}, \mathrm{H}_{\text {aromatic }}\right), 6.98-7.01$ (d, J=8.8 Hz, 2H, $\mathrm{H}_{\text {aromatic }}$ ), 7.27 (s, 4H, NH ${ }_{2}$ ), 7.39-7.43 (dd, J=8 Hz, 2H, $\mathrm{H}_{\text {aromatic }}$ ), 7.66-7.68 (d, J=8.4 Hz, 2H, $\mathrm{H}_{\text {aromatic }}$ ), 7.77-7.80 (d, $\left.\mathrm{J}=8.8 \mathrm{~Hz}, 2 \mathrm{H}, \mathrm{H}_{\text {aromatic }}\right), 8.18-8.20\left(\mathrm{~d}, \mathrm{~J}=8.4 \mathrm{~Hz}, 2 \mathrm{H}, \mathrm{H}_{\text {aromatic }}\right), 10.30(\mathrm{~s}, 2 \mathrm{H}, \mathrm{OH})$.

3,9-diamino-1,7-bis(4-isopropylphenyl)-1,7-dihydrochromeno[8,7-h]chromene-2,8-dicarbonitrile (4i): 82\%, Yellow solid, m.p = 315-320 ${ }^{\circ} \mathrm{C}$ (decomp.), IR $(\mathrm{KBr}) \vee\left(\mathrm{cm}^{-1}\right)$ : $3492\left(\mathrm{NH}_{2}\right), 3379\left(\mathrm{NH}_{2}\right), 2198(\mathrm{CN}), 1651\left(\mathrm{NH}_{2}\right.$ bending), 1596, 1455, 1386, 1272, 1232, 1187, 1086 (C-0), 755; ${ }^{1} \mathrm{H}$ NMR (DMSO-d6, $\left.400 \mathrm{MHz}\right) \delta$ (ppm): $1.14\left(\mathrm{~s}, 6 \mathrm{H}, \mathrm{CH}_{3}\right), 1.16\left(\mathrm{~s}, 6 \mathrm{H}, \mathrm{CH}_{3}\right), 2.80-2.83(\mathrm{~m}, 2 \mathrm{H}, \mathrm{CH}) 4.84\left(\mathrm{~s}, 2 \mathrm{H}, \mathrm{CH}_{\text {benzyl }}\right), 7.12\left(\mathrm{br} . \mathrm{s}, 4 \mathrm{H}, \mathrm{NH}_{2}\right), 7.13-$ $7.27\left(\mathrm{~m}, 10 \mathrm{H}, \mathrm{H}_{\text {aromatic }}\right), 7.85-7.88\left(\mathrm{dd}, \mathrm{J}=8.4 \mathrm{~Hz}, 2 \mathrm{H}, \mathrm{H}_{\text {aromatic }}\right)$.

3,9-diamino-1,7-bis(4-methylphenyl)-1,7-dihydrochromeno[8,7-h]chromene-2,8-dicarbonitrile (4j): 85\%, Yellow solid, m.p =310-320 $\mathrm{C}$ (decomp.), IR $(\mathrm{KBr}) \vee\left(\mathrm{cm}^{-1}\right)$ : $3454\left(\mathrm{NH}_{2}\right), 3325\left(\mathrm{NH}_{2}\right), 3202,2922$, 2196(CN), 1659 ( $\mathrm{NH}_{2}$ bending), 1596, 1500, 1388, 1282, 1238, 1187, 1084 (C-0), 854, 763; ${ }^{1} \mathrm{H}$ NMR (DMSO-d6, $400 \mathrm{MHz}) \delta$ (ppm): $2.07\left(\mathrm{~s}, 6 \mathrm{H}, \mathrm{CH}_{3}\right), 5.40$ (s, 2H, $\left.\mathrm{CH}_{\text {benzyl }}\right), 7.09-7.13\left(\mathrm{~m}, 2 \mathrm{H}, \mathrm{H}_{\text {aromatic }}\right), 7.22-$ $7.29\left(\mathrm{~m}, 8 \mathrm{H}, \mathrm{H}_{\text {aromatic }}\right.$ and $\left.\mathrm{NH}_{2}\right), 7.37-7.40\left(\mathrm{~m}, 2 \mathrm{H}, \mathrm{H}_{\text {aromatic }}\right), 7.61-7.63\left(\mathrm{dd}, \mathrm{J}=8 \mathrm{~Hz}, 2 \mathrm{H}, \mathrm{H}_{\text {aromatic }}\right), 7.86-$ $7.88\left(\mathrm{dd}, \mathrm{J}=8.8 \mathrm{~Hz}, 2 \mathrm{H}, \mathrm{H}_{\text {aromatic }}\right)$.

3,9-diamino-1,7-bis(4-nitrophenyl)-1,7-dihydrochromeno[8,7-h]chromene-2,8 dicarbonitrile (4I): 94\%, Yellow solid, m.p. $>300^{\circ} \mathrm{C}$ (decomp.), IR (KBr) v $\left(\mathrm{cm}^{-1}\right)$ : $3441\left(\mathrm{NH}_{2}\right), 3336\left(\mathrm{NH}_{2}\right), 3196,2190(\mathrm{CN}), 1655\left(\mathrm{NH}_{2}\right.$ bending), 1597, 1527, 1387, 1350, 1281, 1187, 1082 (C-0), 800, 728; ${ }^{1}$ H NMR (DMSO-d6, 400 MHz) $\delta$ 
(ppm): 5.21 (s, $\left.2 \mathrm{H}, \mathrm{CH}_{\text {benzyl }}\right), 7.28-7.30\left(\mathrm{~m}, 4 \mathrm{H}, \mathrm{H}_{\text {aromatic }}\right), 7.34$ (br.s, $\left.4 \mathrm{H}, \mathrm{NH}_{2}\right), 7.60-7.73\left(\mathrm{~m}, 6 \mathrm{H}, \mathrm{H}_{\text {aromatic }}\right.$ ), 7.90-7.92 (d, J =8 Hz, 2H, $\mathrm{H}_{\text {aromatic }}$ ), 8.12 (br.s, $2 \mathrm{H}, \mathrm{H}_{\text {aromatic }}$ ).

3,9-diamino-1,7-bis(2,3-dimethoxyphenyl)-1,7-dihydrochromeno[8,7-h]chromene-2,8-dicarbonitrile (4n): 83\%, Yellow solid, m.p >300 $\mathrm{C}$ (decomp.), IR (KBr) v $\left(\mathrm{cm}^{-1}\right)$ : $3430\left(\mathrm{NH}_{2}\right), 3315\left(\mathrm{NH}_{2}\right), 2195(\mathrm{CN}), 1654$ ( $\mathrm{NH}_{2}$ bending), 1599, 1477, 1386, 1284, 1077 (C-0), 766; ${ }^{1} \mathrm{H}$ NMR (DMSO-d6, $\left.400 \mathrm{MHz}\right) \delta$ (ppm): 3.55 (s, $\left.6 \mathrm{H}, \mathrm{CH}_{3} \mathrm{O}\right), 3.73\left(\mathrm{~s}, 6 \mathrm{H}, \mathrm{CH}_{3} \mathrm{O}\right), 5.06\left(\mathrm{~s}, 2 \mathrm{H}, \mathrm{CH}_{\text {benzyl }}\right), 6.62-6.64$ (d, J=8 Hz, 2H, $\left.\mathrm{H}_{\text {aromatic }}\right), 6.87-6.89$ (dd, J=8 $\mathrm{Hz}, 2 \mathrm{H}, \mathrm{H}_{\text {aromatic }}$ ), 6.94-6.98 (dd, J=8, 2H, $\mathrm{H}_{\text {aromatic }}$ ), 7.07 (br.s, $4 \mathrm{H}, \mathrm{NH}_{2}$ ), 7.11-7.13 (d, J=8.4 Hz, 2H, $\left.\mathrm{H}_{\text {aromatic }}\right), 7.81-7.83\left(\mathrm{~d}, \mathrm{~J}=8.4 \mathrm{~Hz}, 2 \mathrm{H}, \mathrm{H}_{\text {aromatic }}\right)$.

\section{Conclusion}

In the current study, we introduced dendritic silica nanomaterials (KCC-1) with fibrous pore structure possess as a mild, efficient, high activity and stability catalyst for the one-pot synthesis of 2-Amino chromenes by multicomponent reactions under ultrasonic irradiation. This enhancement in activity was explained on the basis of the excellent accessibility of the active sites due to the open and flexible fibrous structure of KCC-1, as well as the different amine groups present on the surface. The novel fibrous nanosilica spheres (KCC-1) nanocatalyst was characterized using FT-IR, SEM, TEM, EDX, XRD, TGA and BET techniques. The catalyst showed excellent efficiency and could convert $>92 \%$ of the substrates to the target molecules. We believe, our procedure will find important applications in the synthesis of 2-Amino chromenes, which represents a major advantage for reactions from the stability of this catalyst and short reaction time for synthesis of heterocyclic compounds using ultrasonic irradiation. This method offers several advantages including heterogeneous, easy separation, thermal stability, high surface area and resistance of the catalyst under ultrasonic irradiation, short reaction time, simple experimental workup procedure, lower loading of the catalyst compared with the other methods, easy product separation, and purification, which makes it a suitable process for the synthesis of 2-amino chromens.

\section{Declarations}

\section{Acknowledgements}

The authors are grateful to the University of Kashan for supporting this work.

\section{References}

1. J. Skommer, D. Wlodkowic, M. Matto, M. Eray, J. Pelkonen, HA14-1, a small molecule Bcl-2 antagonist, induces apoptosis and modulates action of selected anticancer drugs in follicular lymphoma B cells. Leuk. Res. 30 (2006) 322-331. https:/doi.org/10.1016/ j.leukres. 2005.08.022.

2. J.L. Wang, D. Liu, Z.J. Zhang, S. Shan, X. Han, S.M. Srinivasula, C.M. Croce, E.S. Alnemri, Z. Huang, Structure-based discovery of an organic compound that binds Bcl-2 protein and induces apoptosis of 
tumor cells. Proc. Natl. Acad. Sci. U.S.A. 97 (2000) 7124-7129. https://doi.org/ 10.1073/pnas.97.13.7124.

3. P.W. Smith, S.L. Sollins, D.P. Howes, P.C. Cherry, I.D. Starkey, K.N. Cobley, H. Weston, J. Scicinski, A. Merritt, A. Whittington, P. Wyatt, N. Taylor, D. Green, R. Bethell, S. Madar, R.J. Fenton, P.J. Morley, T. Pateman, A. Beresford, Dihydropyrancarboxamides Related to Zanamivir: A New Series of Inhibitors of Influenza Virus Sialidases. 1. Discovery, Synthesis, Biological Activity, and Structure-Activity Relationships of 4-Guanidino- and 4-Amino-4H-pyran-6-carboxamides, J. Med. Chem. 41 (1998) 787797. https://doi.org/10.1021/jm970374b.

4. A. Martinez-Grau, J.L. Marco, Friedländer reaction on 2-amino-3-cyano-4H-pyrans: Synthesis of derivatives of $4 \mathrm{H}$-pyran [2,3-b] quinoline, new tacrine analogues, Bioorg. Med. Chem. Lett. 7 (1997) 3165-3170. https://doi.org/10.1016/S0960-894X(97)10165-2.

5. D.R. Anderson, S. Hegde, E. Reinhard, L. Gomez, W.F. Vernier, L. Lee, S. Liu, A. Sambandam, P.A. Sinder, L. Masih, Aminocyanopyridine inhibitors of mitogen activated protein kinase-activated protein kinase 2 (MK-2), Bioorg. Med. Chem. Lett. 15 (2005) 1587-1590. https://doi.org/10.1016/j.bmcl.2005.01.067.

6. S.J. Mohr, M.A. Chirigios, F.S. Fuhrman, J.W. Pryor, Pyran copolymer as an effective adjuvant to chemotherapy against a murine leukemia and solid tumor, Cancer Res. 35 (1975) 3750-3754. https://pubmed.ncbi.nlm.nih.gov/1192431/

7. C. Wiener, C.H. Schroeder, B.D. West, K.P. Link, Studies on the 4-hydroxycoumarins. XVIII. 3-[a(acetamidomethyl)benzyl]-4-hydroxycoumarin and related products. J. Org. Chem. 27 (1962) 30863088. https://doi.org/10.1021/jo01056a024.

8. F.M. Abdel Galil, B.Y. Riad, S.M. Sherif, M.H. Elnagdi, Activated nitriles in heterocyclic synthesis: a navel synthesis of 4-azoloyl-2-aminoquinolines. Chem. Lett. 11 (1982) 1123-1126. https://doi.org/10.1246/cl.1982.1123

9. W. Kemnitzer, S. Kasibhatla, S. Jiang, H. Zhang, J. Zhao, S. Jia, L. Xu, C. Crogan-Grundy, R. Denis, N. Barriault, L. Vaillancourt, S. Charron, J. Dodd, G. Attardo, D. Labrecque, S. Lamothe, H. Gourdeau, B. Tseng, J. Drewe, S.X. Cai, Discovery of 4-aryl-4H-chromenes as a new series of apoptosis inducers using a cell- and caspase-based high-throughput screening assay. 2. Structure-activity relationships of the 7- and 5-, 6-, 8-positions. Bioorg. Med. Chem. Lett. 15 (2005) 4745-4751. https://doi.org/10.1016/j.bmcl. 2005.07.066

10. D. Chauhan, S. Hashim, P. Rani, S. Kumar, N. Shrimal, D. Shastri, and et al. Discovery of novel substituted N-(6-Chloro-3-cyano-4-phenyl-4H-chromen-2-yl)-2-(4-chloro-phenoxy)-acetamide for biphasic anticancer and anticonvulsant activities. Med. Chem. 17 (2021) 203-215. https://doi.org/10.2174/1573406415666191206101617.

11. V. Polshettiwar, B. Baruwati, R.S. Varma, Magnetic nanoparticle-supported glutathione: a conceptually sustainable organocatalyst, Chem. Commun. 14 (2009) 1837-1839. https://doi.org/10.1039/B900784A. 
12. E.A. Hafez, M.H. Elnagdi, A.G.A. Elagamey, F.M.A.A. El-Taweel, Nitriles in heterocyclic synthesis: Novel synthesis of benzo[c]-coumarin and of benzo[c]pyrano[3,2-c] quinolone derivatives. Heterocycles. 26 (1987) 903-907. https://doi.org/10.3987/r-1987-04-0903

13. A.M. ElAgrody, M.H. ElHakiem, M.S. Abd El-Latif, A.H. Fakery, E.S.M. El-Sayed, K.A. El-Ghareab, Synthesis of pyrano [2,3-d] pyrimidine and pyrano [3,2-e] [1,2,4] triazolo [2,3-c] pyrimidine derivatives with promising antibacterial activity. Acta. Pharm. 50 (2000) 111-120.

14. M.A. Sofan, F.M.A.A. El-Taweel, M.H. Elnagdi, Studies on cinnamonitriles: The reaction of cinnamonitriles with cyclopentanone. Liebigs. Ann. Chem. 9 (1989) 935-936. https://doi.org/10.1002/jlac.198919890246

15. A. Agarwal, K. Srivastava, S.K. Puri, P.M. Chauhan, Synthesis of 2,4,6-trisubstituted pyrimidines as antimalarial agents. Bioorg. Med. Chem. Lett. 15 (2005) 4645-4650. https://doi.org/10.1016/j.bmc.2005.04.061.

16. W. Kemnitzer, J. Drewe, S. Jiang, H. Zhang, W. Wang, S. Lia, L. Xu, C. Crogan-Grundy, R. Denis, N. Barriault, L. Villacourt, S. Charron, J. Dodd, G. Attardo, D. Labrique, S. Lamothe, H. Gourdeau, B. Tseng, J. Drewe, S.X. Cia, Discovery of 4-Aryl-4H-chromenes as a New Series of Apoptosis Inducers Using a Cell- and Caspase-based High-Throughput Screening Assay. 1. Structure-Activity Relationships of the 4-Aryl Group. J. Med. Chem. 47 (2004) 6299-6310. https://doi.org/10.1021/jm049640t

17. A. Mobinikhaledi, H. Moghanian, F. Sasani, Microwave-Assisted One-Pot Synthesis of 2-Amino-2chromenes Using Piperazine as a Catalyst Under Solvent-Free Conditions. Synthesis and Reactivity in Inorganic, Metal-Organic, and Nano-Metal Chem. 41 (2011) 262-265. https://doi.org/10.1080/15533174.2011.555857.

18. A.F. Mahmoud, F. Fathy, M.A. Amira, Microwave Assisted One-pot Synthesis of 2-Amino-4Hchromenes and Spiropyrano[2,3-d]pyrimidine. Chin. J. Chem. 28 (2010) 9196. https://doi.org/10.1002/cjoc.201090041.

19. A. Khazaei , E. Bashirian, A. Ranjbaran, M. Khazaei, A.R. Moosavi-Zare, The Synthesis of 2,11Diamino-4,9-diphenyl-4,9-dihydrobenzo [f] pyrano[3,2-h]chromene-3,10-dicarbonitrile Derivatives using Triethanolammonium Acetate as a Green Ionic Liquid. J. Chin. Chem. Soc. 64 (2017) 757-763. https://doi.org/10.1002/jccs.201700019.

20. M. Mirza-Aghayan, S. Nazmdeh, R. Boukherroub, M. Rahimifard, A.A. Tarlani, M. AbolghasemiMalakshah, Convenient and Efficient One-Pot Method for the Synthesis of 2-Amino-tetrahydro-4Hchromenes and 2-Amino-4H-benzo[h]-chromenes Using Catalytic Amount of Amino-Functionalized MCM-41 in Aqueous Media. Synth. Commun. 43 (2013) 1499-1507. https://doi.org/10.1080/00397911.2011.643438.

21. M. Kidwai, S. Saxena, M.K. Rahman Khan, S.S. Thukral, Aqua mediated synthesis of substituted 2amino-4H-chromenes and in vitro study as antibacterial agents. Bioorg. Med. Chem. Lett. 15 (2005) 4295-4298. https://doi.org/10.1016/j.bmcl.2005.06 .041 
22. M.N. Soltani Rad, Ultrasound promoted mild and facile one-pot, three component synthesis of $2 \mathrm{H}$ indazoles by consecutive condensation, $\mathrm{C}-\mathrm{N}$ and N-N bond formations catalysed by copper-doped silica cuprous sulphate (CDSCS) as an efficient heterogeneous nano-catalyst. Ultrason. Sonochem. 34 (2017) 865-872. https://doi.org/10.1016/ j.ultsonch.2016.07.026

23. D.S. Karousos, K.I. Desdenakis, P.M. Sakkas, G. Sourkouni, B.G. Pollet, C. Argirusis, Sonoelectrochemical one-pot synthesis of Pt-Carbon black nanocomposite PEMFC electrocatalyst. Ultrason. Sonochem. 35 (2017) 591-597. https://doi.org/10.1016/j.ultsonch. 2016.05.023

24. M. Mirza-Aghayan, M.M. Tavana, R. Boukherroub, Sulfonated reduced graphene oxide as a highly efficient catalyst for direct amidation of carboxylic acids with amines using ultrasonic irradiation. Ultrason. Sonochem. 29 (2016) 371-379. https://doi.org/10.1016/j.ultsonch.2015.10.009

25. J. Safaei-Ghomi, F. Eshteghal, H. Shahbazi-Alavi, A facile one-pot ultrasound assisted for an efficient synthesis of benzo[g]chromenes using Fe304/polyethylene glycol (PEG) core/shell nanoparticles. Ultrason. Sonochem. 33 (2016) 99-105. https://doi.org/10.1016/10.1016/j.ultsonch.2016.04.025.

26. J. Safaei-Ghomi, S. Paymard-Samani, H. Shahbazi-Alavi, S. Zahedi, Sonochemical synthesis of 5substituted $1 \mathrm{H}$-tetrazoles catalyzed by ZrP2O7 nanoparticles and regioselective conversion into new 2,5-disubstituted tetrazoles. Z. Naturforsch. 70 (2015) 819-828. https://doi.org/ 10.1515/znb-20150070 .

27. Y.T. Shah, A.B. Pandit, V.S. Moholkar, Cavitation Reaction Engineering, Springer, US, Boston, MA, 1999 http://link.springer.com/10.1007/978-1-4615-4787-7 (accessed February 9, 2016).

28. J. Zevnik, M. Dular, Cavitation bubble interaction with a rigid spherical particle on a microscale. Ultrason. Sonochem. 69 (2020) 1052-52. https://doi.org/10.1016/j.ultsonch.2020. 105252

29. H. Naeimi, F. Kiani, Ultrasound-promoted one-pot three component synthesis of tetrazoles catalyzed by zinc sulfide nanoparticles as a recyclable heterogeneous catalyst. Ultrason. Sonochem. 27 (2015) 408-415. https://doi.org/10.1016/j.ultsonch.2015.06.008

30. M. Masjedi-Arani, M. Salavati-niasari, A simple sonochemical approach for synthesis and characterization of Zn2SiO4 nanostructures, Ultrason. Sonochem. 29 (2016) 226-235. https://doi.org/10.1016/j.ultsonch.2015.09.020

31. a) V. Polshettiwar, B. Baruwati, R.S. Varma, Self-Assembly of Metal Oxides into Three-Dimensional Nanostructures: Synthesis and Application in Catalysis. A.C.S. Nano, 3 (2009) 728-736. https://doi.org/10.1021/nn800903p; b) V. Polshettiwar, R.S. Varma, Green chemistry by nanocatalysis, Green Chem. 12 (2010) 743-754. https://doi.org/10.1039/ B921171C.

32. V. Polshettiwar, D. Cha, X. Zhang, J.M. Basset, High-Surface-Area Silica Nanospheres (KCC-1) with a Fibrous Morphology. Angew. Chem. 122 (2010) 9846-9850. https://doi.org/10.1002/ange.201003451.

33. V. Polshettiwar, J. Thivolle-Cazat, M. Taoufik, F. Stoffelbach, S. Norsic, J.M. Basset, “Hydrometathesis" of Olefins: A Catalytic Reaction Using a Bifunctional Single-Site Tantalum Hydride Catalyst Supported on Fibrous Silica (KCC-1) Nanospheres. Angew. Chem. Int. Ed. 50 (2011) 27472751. https://doi.org/10.1002/anie.201007254. 
34. N. Bayal, B. Singh, R. Singh, and et al. Size and Fiber Density Controlled Synthesis of Fibrous Nanosilica Spheres (KCC-1). Sci. Rep. 6 (2016) 24888-24899. https://doi.org/10.1038/srep24888.

35. A. Fihri, D. Cha, M. Bouhrara, N. Almana, V. Polshettiwar, Fibrous Nano-Silica (KCC-1)-Supported Palladium Catalyst: Suzuki Coupling Reactions Under Sustainable Conditions, Chem.Sus.Chem. 5 (2012) 85-89. https://doi.org/10.1002/cssc.201100379.

36. P. Gautam, M. Dhiman, V. Polshettiwar, B.M. Bhanage, KCC-1 supported palladium nanoparticles as an efficient and sustainable nanocatalyst for carbonylative Suzuki-Miyaura cross-coupling. Green Chem. 18 (2016) 5890-5899. https://doi.org/10.1039/C6GC02012G.

37. R.S. Varma, R. Dahiya, An expeditious and solvent-free synthesis of 2-amino-substituted isoflav-3enes using microwave irradiation. J. Org. Chem. 63 (1998) 8038-8041. https://doi.org/10.1021/jo980985r.

38. S.M. Sadeghzadeh, R. Zhiania, S. Emrania, Pd/APTPOSS@KCC-1 as a new and efficient support catalyst for C-H activation. R.S.C. Adv. 7 (2017) 24885-24894. https://doi.org/10.1039/C7RA03698A.

39. X. Huang, Z. Tao, J.C. Praskavich, Jr., A. Goswami, J.F. Al-Sharab, T. Minko, V. Polshettiwar, T. Asefa, Dendritic Silica Nanomaterials (KCC-1) with Fibrous Pore Structure Possess High DNA Adsorption Capacity and Effectively Deliver Genes In Vitro, Langmuir, 30 (2014) 10886-10898. https://doi.org/10.1021/la501435a.

40. Z. Sun, D. Guo, L. Zhang, H. Li, B. Yanga, S. Yan, Multifunctional fibrous silica composite with high optical sensing performance and effective removal ability toward $\mathrm{Hg} 2+$ ions. J. Mater. Chem. B, 3 (2015) 3201-3210. https://doi.org/10.1039/C5TB00038F.

41. M.E. Davis, Ordered porous materials for emerging applications. Nature, 417 (2002) 813-821. https://doi.org/10.1038/nature00785.

42. A. Corma, H. Garcia, Crossing the borders between homogeneous and heterogeneous catalysis: developing recoverable and reusable catalytic systems. Top. Catal. 48 (2008) 8-31. https://doi.org/10.1007/s11244-008-9056-5.

43. S. Verma, M. Nandi, A. Modak, S.L. Jain, A. Bhaumik, Novel organic-inorganic hybrid mesoporous silica supported oxovanadium schiff base for selective oxidation of alcohols. Adv. Synth. Catal. 353 (2011) 1897-1902. https://doi.org/10.1002/adsc.201100018.

44. A. Christian, W. Veronika, B. Christoph, B. Thomas, Multifunctional mesoporous silica nanoparticles as a universal platform for drug delivery. Chem. Mater. 26 (2014) 435-451. https://doi.org/10.1021/cm402592t.

45. J.G. Huddleston, A.E. Visser, W.M. Reichert, H.D. Willauer, G.A. Brokera, R.D. Rogers, Characterization and comparison of hydrophilic and hydrophobic room temperature ionic liquids incorporating the imidazolium cation. Green Chem. 3 (2001) 156-164. https://doi.org/10.1039/B103275P.

46. S. Azizi, J. Soleymani, M. Hasanzadeh, Nanocomposites, 6 (2020) 31-40. https://doi.org/10.1080/20550324.2019.1708634. 
47. K.E.A. AbouAitah, A.A. Farghali, A. Swiderska-Sroda, W. Lojkowski, A.F.M. Razin, M.H. Khedr, Mesoporous silica materials in drug delivery system: $\mathrm{pH} /$ glutathione-responsive release of poorly water-soluble pro-drug quercetin from two and three-dimensional pore-structure nanoparticles. J. Nanomed. Nanotechnol. 7 (2016) 1-12. https://doi.org/10.4172/ 2157-7439.1000360.

48. N. Khantan, N. Shadjou, M. Hasanzadeh, Synthesize of dendritic fibrous nano-silica functionalized by cysteine and its application as advanced adsorbent, Nanocomposites, 5 (2019) 104-113. https://doi.org/10.1080/20550324.2019.1669925.

49. A.M. Shestopalov, Yu.M. Emelianova, V.N. Nesterov, One_step synthesis of substituted 2-amino-4Hchromenes and 2-amino-4H-benzo[f]chromenes. Molecular and crystal structure of 2-amino-3-cyano6-hydroxy-4-phenyl-4H-benzo[f]chromene. Russ. Chem. Bull. 51 (2002) 2238-2243. https://doi.org/10.1023/A:1022135402451

50. M. Hosseini-sarvari, S. Shafiee-haghighi, Multi-component synthesis of 2-amino-4H-chromenes catalysed by nano ZnO in water, Collect. Czech. Chem. Commun. 76 (2011) 1285-1298. https://doi.org/10.1135/cccc2011050.

51. X. Wang, D. Shi, H. Yu, G. Wang, S. Tu, Synthesis of 2-Aminochromene Derivatives Catalyzed by KF/Al2O3, Synth. Commun. 34 (2004) 509-514. https://doi.org/10.1081/SCC-120027291.

\section{Tables}


Table 1

Optimization of reaction condition for the formation of 2-amino-4H-chromenes ${ }^{a, c}$

\begin{tabular}{|c|c|c|c|c|}
\hline Entry & solvent & Catalyst (g) & $\begin{array}{l}\text { Time } \\
(\min )\end{array}$ & Yield $\%$ \\
\hline 1 & DMF & Nano KCC-1@NH 2 (0.05) & 20 & 80 \\
\hline 2 & $\mathrm{CH}_{3} \mathrm{CN}$ & Nano KCC-1@NH 2 (0.05) & 20 & 80 \\
\hline 3 & $\mathrm{H}_{2} \mathrm{O}$ & Nano KCC-1@NH 2 (0.05) & 20 & 90 \\
\hline 4 & THF & Nano KCC-1@NH 2 (0.05) & 20 & 60 \\
\hline 5 & $\mathrm{EtOH}$ & Nano KCC-1@NH 2 (0.05) & 20 & 96 \\
\hline 6 & $\mathrm{EtOH}$ & Nano KCC-1@NH 2 (0.08) & 20 & 96 \\
\hline 7 & $\mathrm{EtOH}$ & Nano KCC-1@NH 2 (0.03) & 20 & 90 \\
\hline 8 & $\mathrm{EtOH}$ & TEA & 20 & 85 \\
\hline 9 & $\mathrm{EtOH}$ & piperidine & 20 & 85 \\
\hline 10 & $\begin{array}{l}\text { EtOH } \\
\text { (reflux) }\end{array}$ & Nano KCC-1@NH 2 (0.05) & 180 & 70 \\
\hline \multicolumn{5}{|c|}{$\begin{array}{l}{ }^{a} \text { Reactions conditions: } \mathrm{p} \text {-chloro benzaldehyde }(1 \mathrm{mmol}), 1,5 \text { - naphtalendiol }(0.05 \mathrm{mmol}) \text {, malononitrile } \\
(1 \mathrm{mmol})\end{array}$} \\
\hline \multicolumn{5}{|c|}{$b_{\text {Isolated yield }}$} \\
\hline Ultras & adiation & & & \\
\hline
\end{tabular}


Table 2

Optimization of reaction condition for the formation of 2-amino-4H-chromenes ${ }^{a, c}$

\begin{tabular}{|c|c|c|c|}
\hline Entry & Power (W) & Time(min) & Yield ${ }^{b}(\%)$ \\
\hline 1 & 50 & 20 & 45 \\
\hline 2 & 60 & 20 & 65 \\
\hline 3 & 70 & 20 & 82 \\
\hline 4 & 80 & 20 & 96 \\
\hline 5 & 90 & 20 & 96 \\
\hline \multicolumn{4}{|c|}{$\begin{array}{l}{ }^{a} \text { Reactions conditions: p-chloro benzaldehyde }(1 \mathrm{mmol}) \text {, malononitrile }(1 \mathrm{mmol}), 1,5 \text { - dinaphtol } \\
\text { compound }(0.5 \mathrm{mmol}) \text {, nano } \mathrm{KCC}-1 @ \mathrm{NH}_{2}(5 \%)\end{array}$} \\
\hline
\end{tabular}

Due to technical limitations, table 3 is only available as a download in the Supplemental Files section.

Table 4. Comparison the results of synthesis of 2-Amino-chromens through the knoevenagel condensation in this research and various reports in the literature

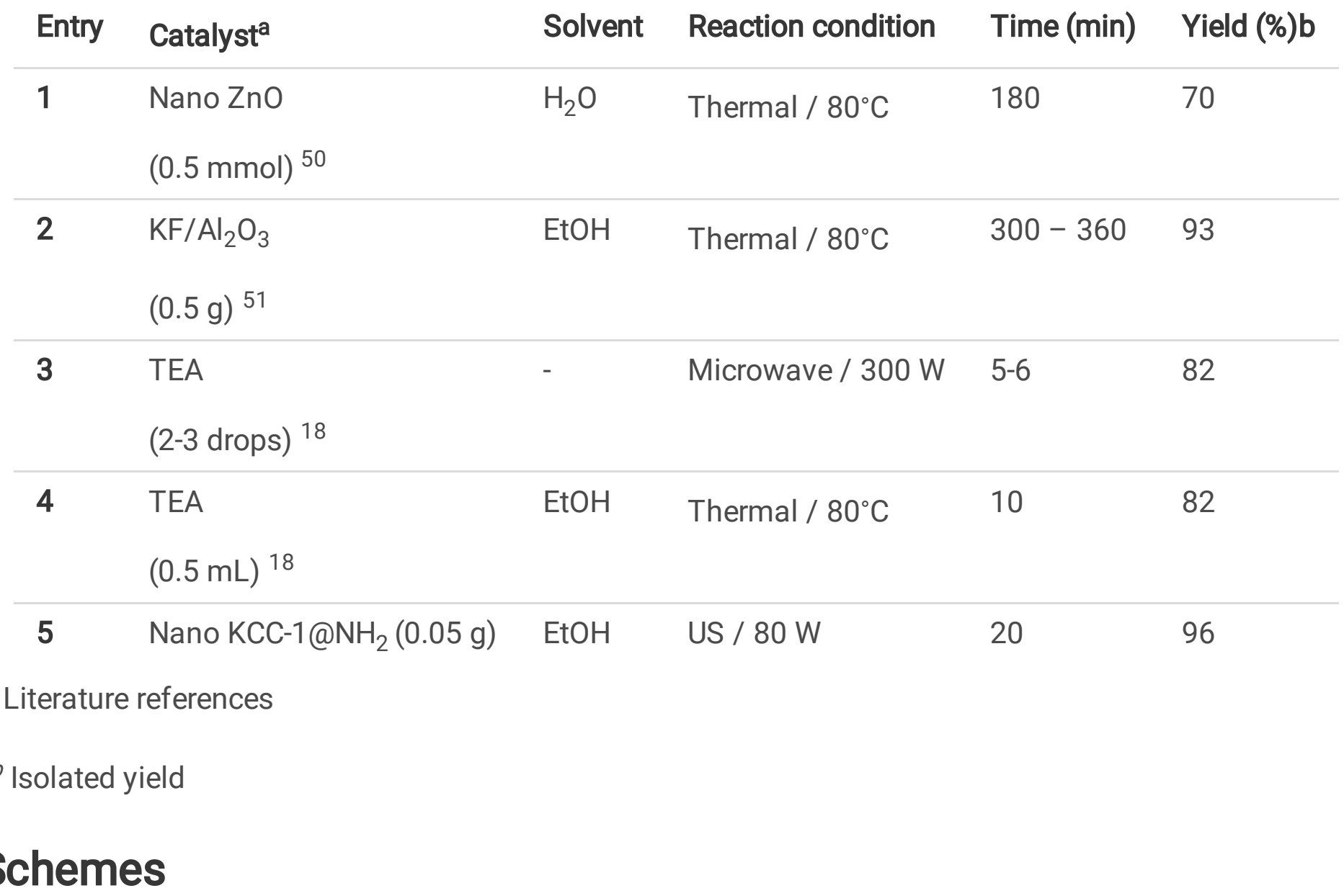


Schemes 1-3 are available in the Supplementary Files section.

Figures

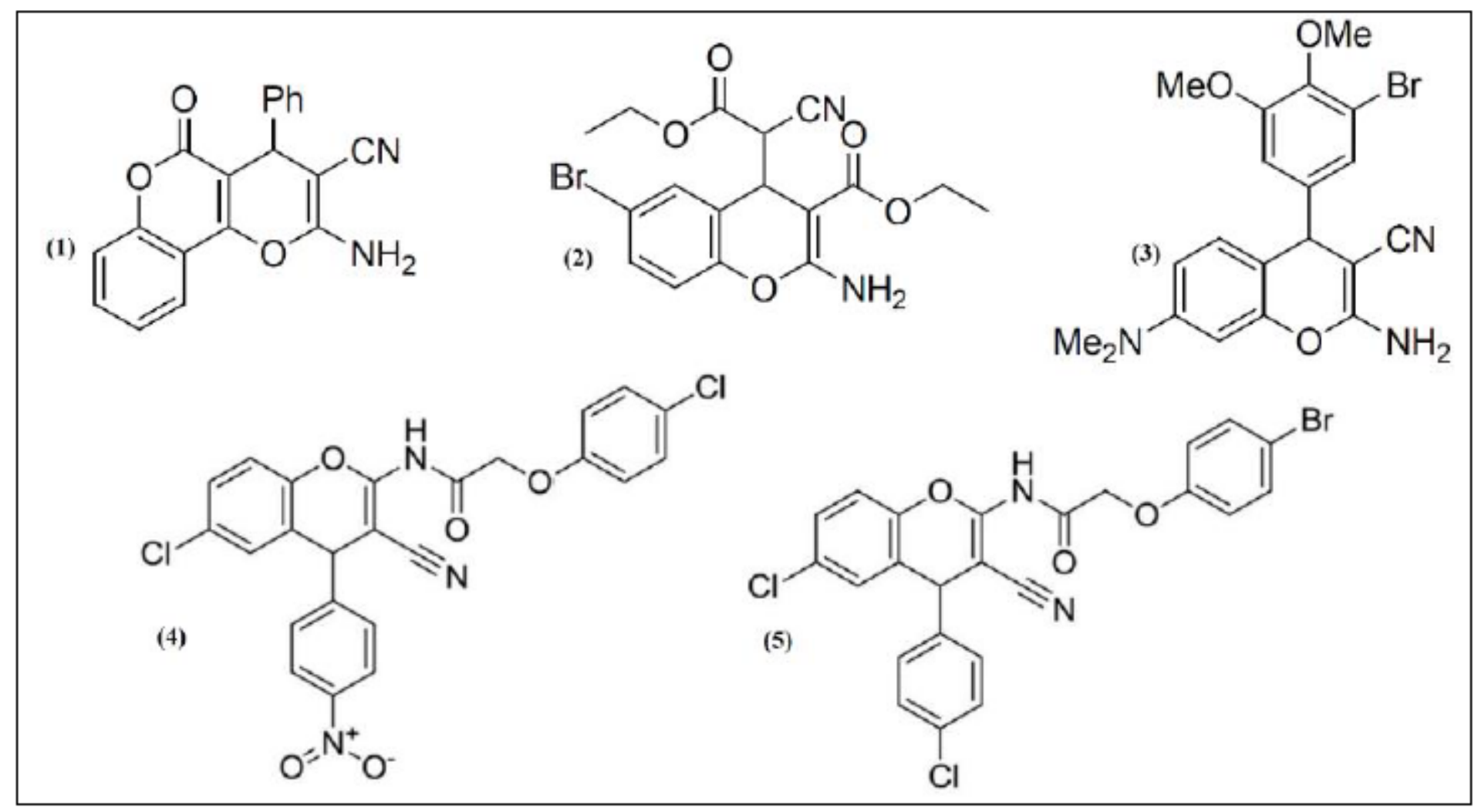

Figure 1

Structures of some 2-amino-4H-chromenes with diverse biological 


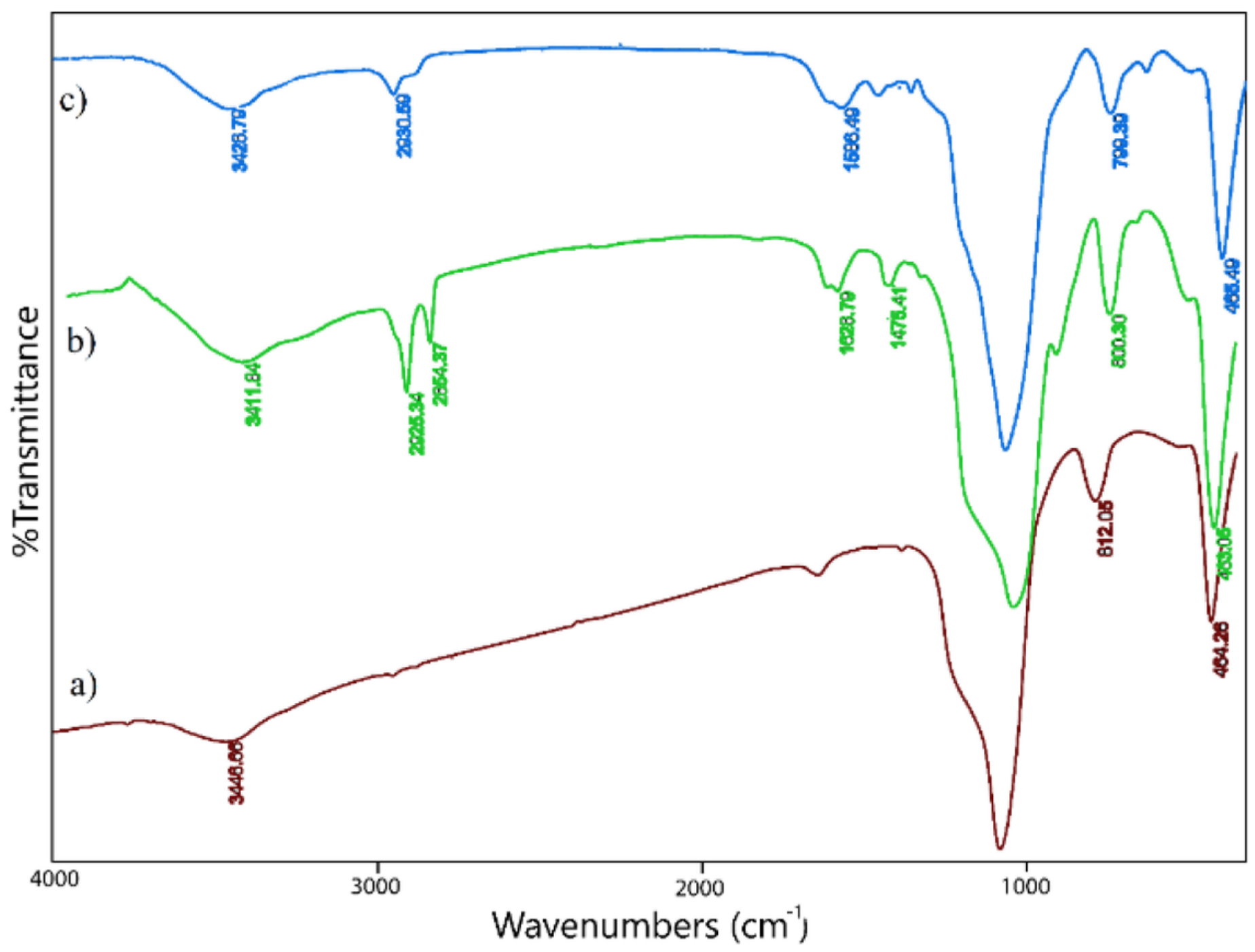

Figure 2

The FT-IR spectra of (a) KCC-1 before calcination, (b) KCC-1 after calcination and (c) KCC-1@NH2 


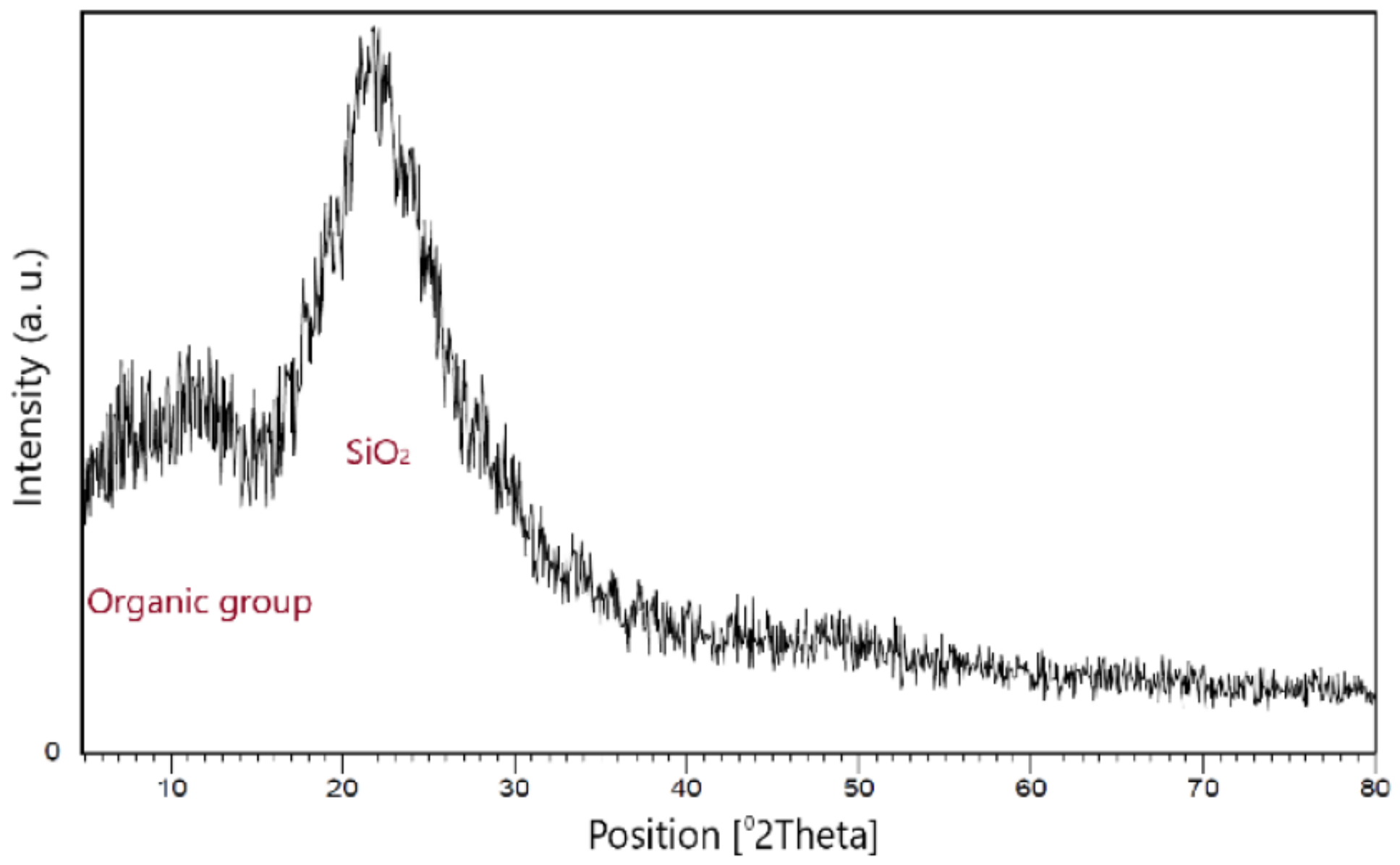

Figure 3

The XRD pattern of nanosphere KCC-1@NH2 


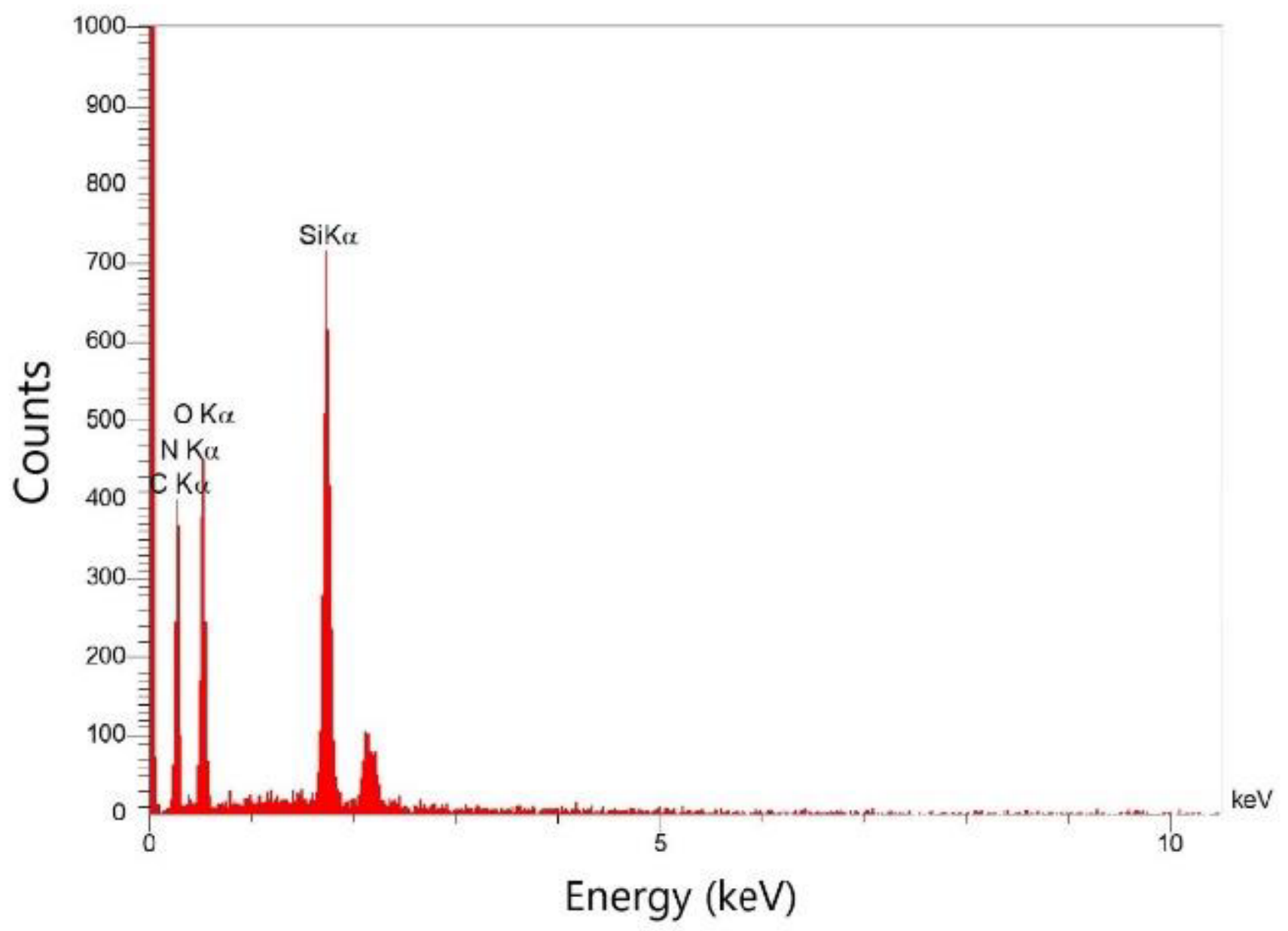

Figure 4

The EDX spectrum of nanosphere KCC-1@NH2 

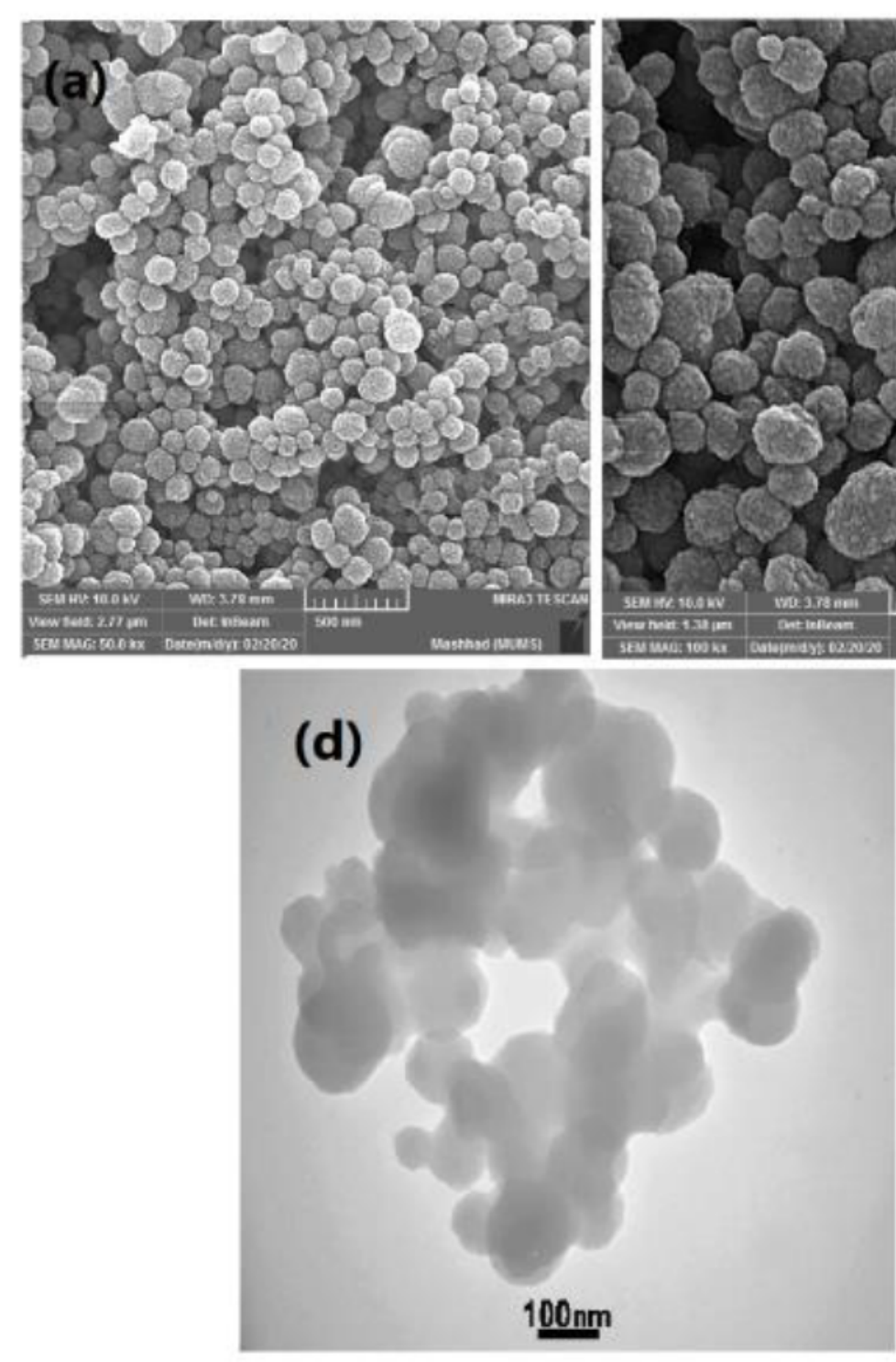
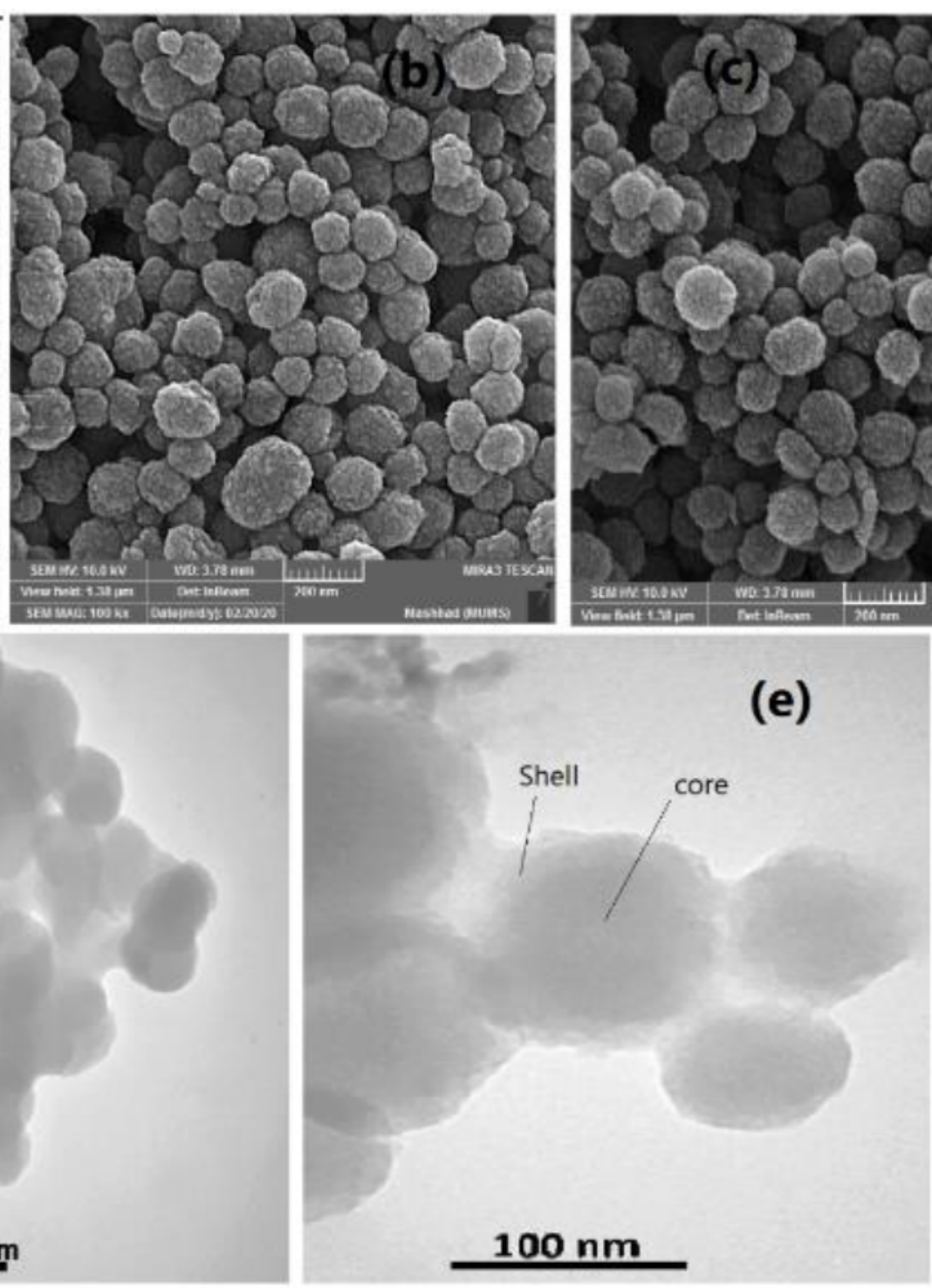

(e)

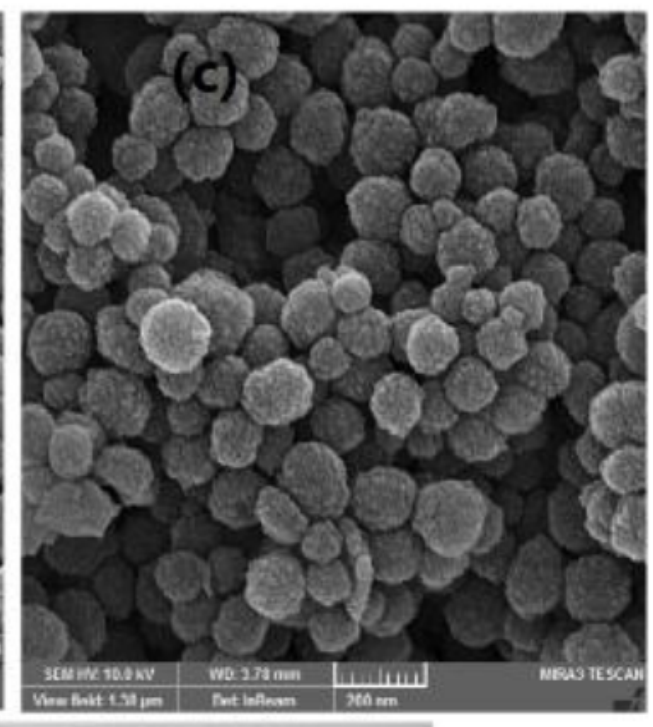

\section{Figure 5}

The SEM image of nanosphere KCC-1@NH2 (a) KCC-1 (b) KCC-1@NH2 before use (c) after reuse of six times, and (d,e) TEM images of KCC-1@NH2. 

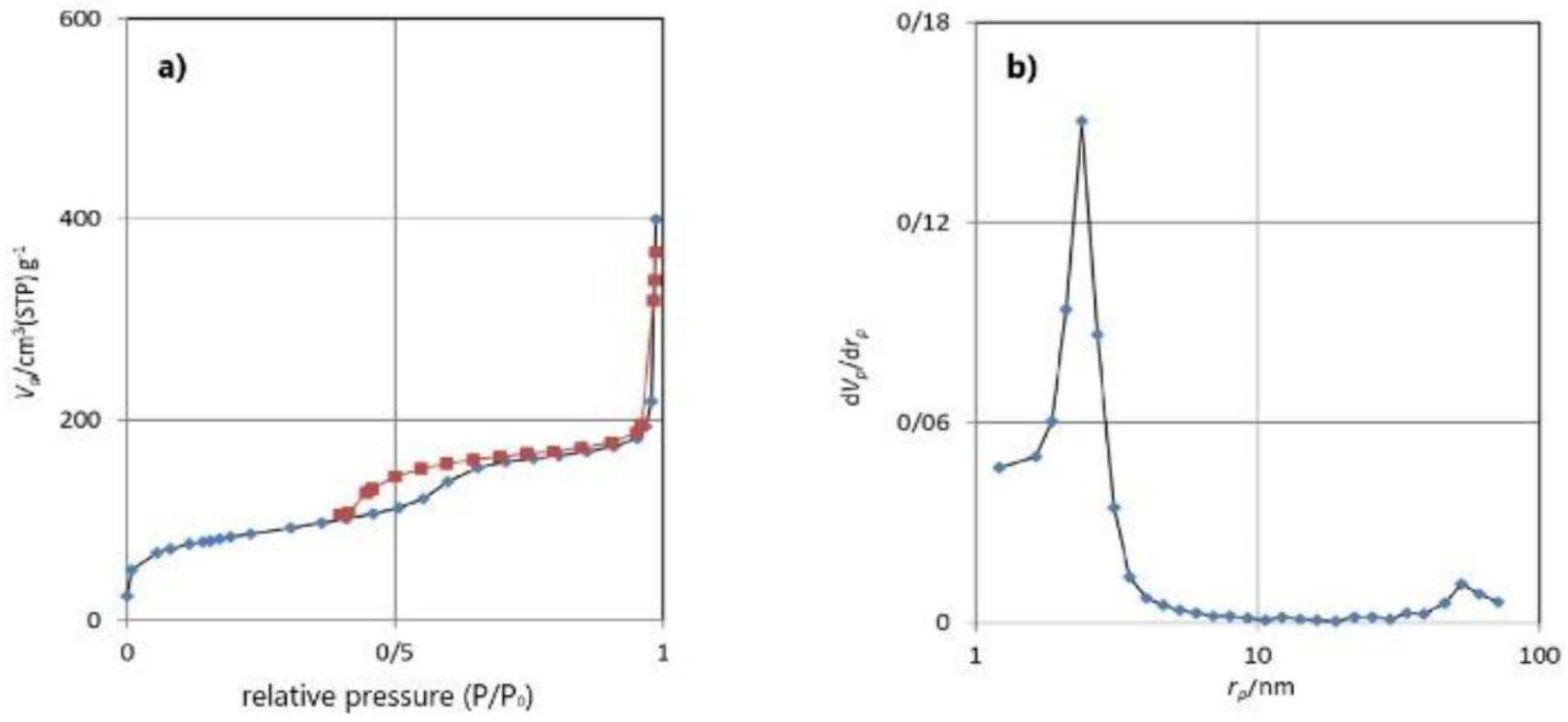

Figure 6

The BETand BJH images of KCC-1@NH2

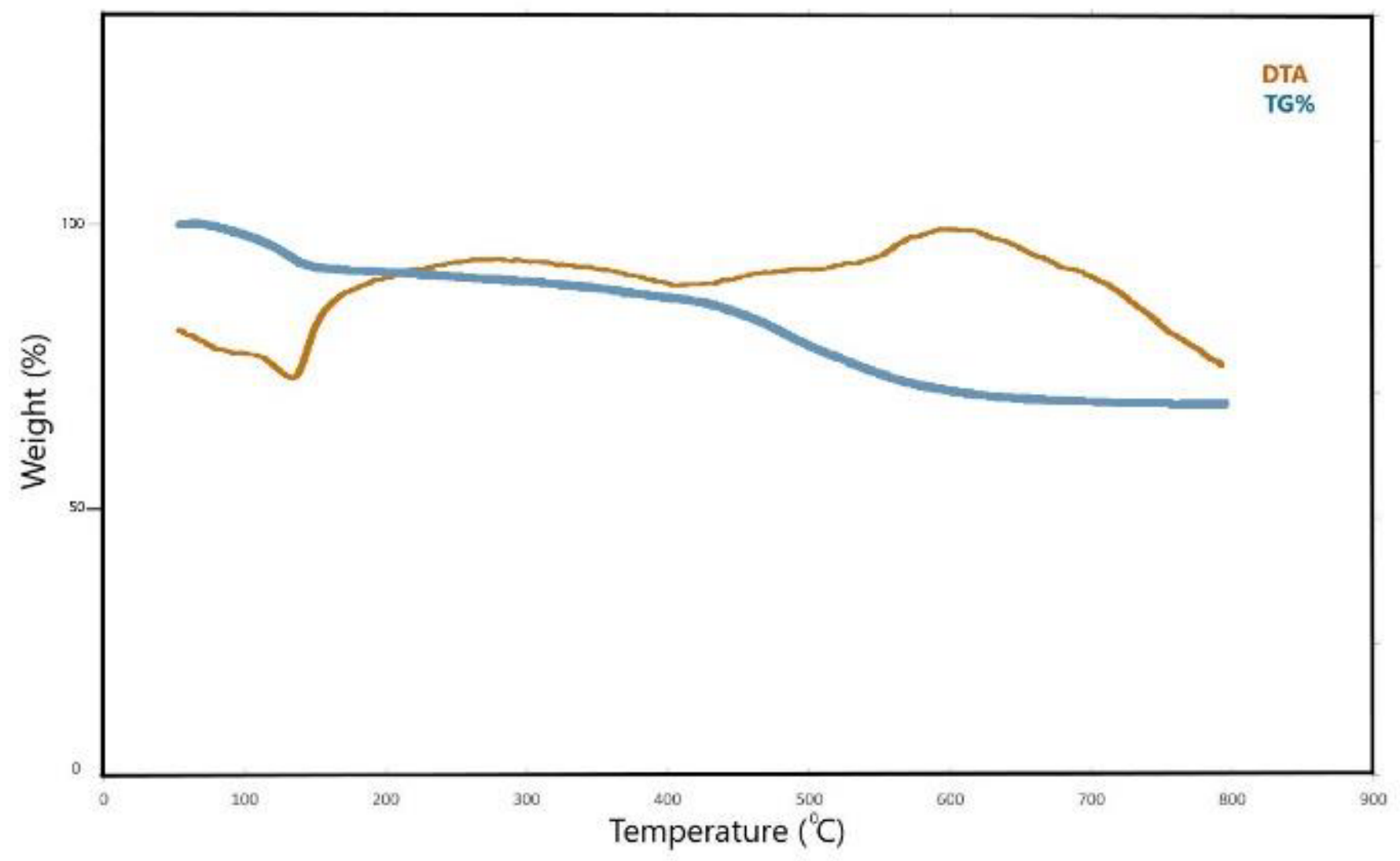

Figure 7 
The TGA and DTA curves of KCC-1@NH2.

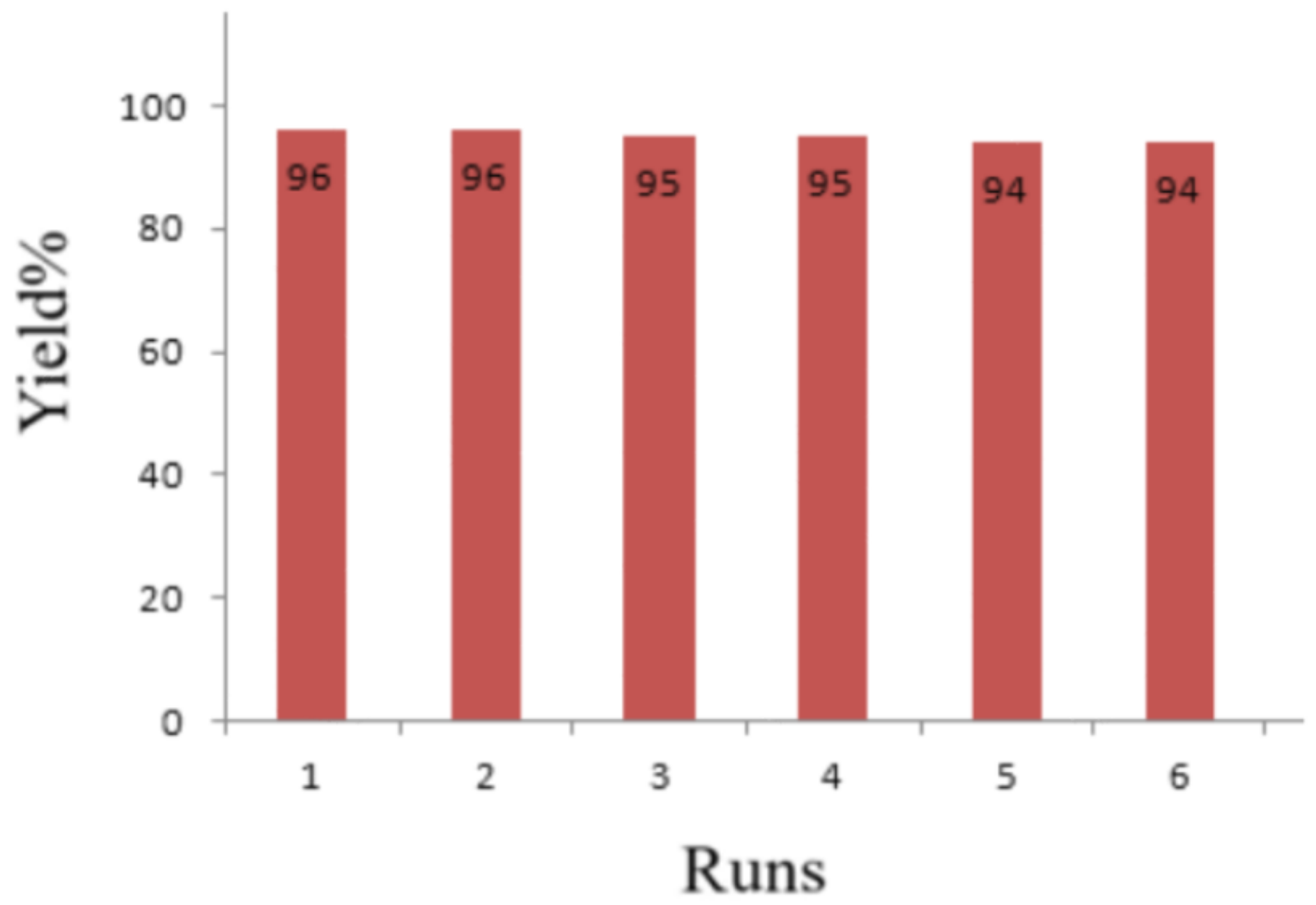

Figure 8

Recovery of nanosphere KCC-1@NH2

\section{Supplementary Files}

This is a list of supplementary files associated with this preprint. Click to download.

- Scheme1.png

- Scheme2.png

- Graphicalabstract.jpg

- Scheme3.png

- supplementary.docx

- Table3.docx 